\title{
NoTE
}

\section{Effects of DHMEQ, a Novel Nuclear Factor- $\kappa B$ Inhibitor, on Beta Cell Dysfunction in INS-1 Cells}

\author{
Yoshifumi SAISHO, HIROSHI HIROSE, CHIHIRO HORIMAI*, KIICHI MIYASHITA**, IZUMI TAKEI*, \\ KAZUO UMEZAWA*** AND HIROSHI ITOH
}

\author{
Department of Internal Medicine, Keio University School of Medicine, Tokyo, Japan \\ *Department of Laboratory Medicine, Keio University School of Medicine, Tokyo, Japan \\ **Institute for Advanced Medical Research, Keio University School of Medicine, Tokyo, Japan \\ ***Department of Applied Chemistry, Faculty of Science and Technology, Keio University, Yokohama, Japan
}

\begin{abstract}
Aims: Recent studies suggest that nuclear factor- $\kappa \mathrm{B}(\mathrm{NF}-\kappa \mathrm{B})$ activation has an important role in leading to beta cell dysfunction in both type 1 and type 2 diabetes. In this study we tested this hypothesis by investigating the effects of dehydroxymethylepoxyquinomicin (DHMEQ), a novel NF- $\kappa$ B inhibitor, on tumor necrosis factor- $\alpha$ (TNF- $\alpha$ )-induced beta cell dysfunction. Methods: INS-1 cells were incubated with TNF- $\alpha$ and with or without DHMEQ for 24 hours. Glucose-stimulated insulin secretion, cell viability, mRNA expression and NF- $\kappa B$ activation were investigated. Results: DHMEQ suppressed TNF- $\alpha$-induced NF- $\mathrm{BB}$ activation and partially ameliorated glucose-stimulated insulin secretion in a dose-dependent manner. DHMEQ also partially ameliorated decreased cell viability and insulin mRNA level induced by TNF- $\alpha$. Conclusion: DHMEQ suppressed NF- $\kappa B$ activation and ameliorated beta cell dysfunction induced by TNF- $\alpha$. Inhibition of activated NF- $\mathrm{KB}$ in beta cells may be important to ameliorate beta cell dysfunction in diabetes.
\end{abstract}

Key words: Dehydroxymethylepoxyquinomicin, Nuclear factor- $\kappa \mathrm{B}$, Tumor necrosis factor- $\alpha$, Glucose-stimulated insulin secretion, Cell viability, INS-1 cells

(Endocrine Journal 55: 433-438, 2008)

TYPE 1 diabetes (T1DM) is characterized by autoimmune destruction of beta cells, which results in a deficit of beta cell mass [1]. Previous studies have shown that transcription factor nuclear factor- $\kappa \mathrm{B}(\mathrm{NF}-\kappa \mathrm{B})$ has a critical role in cytokine-induced beta cell destruction in T1DM [2]. Type 2 diabetes (T2DM) is character-

Received: August 29, 2007

Accepted: January 15, 2008

Correspondence to: Hiroshi HIROSE, M.D., Ph.D., Health Center and Dept. of Internal Medicine, Keio University School of Medicine, 35 Shinanomachi, Shinjuku-ku, Tokyo 160-8582, Japan Abbreviations: T1DM, type 1 diabetes, T2DM, type 2 diabetes, DHMEQ, dehydroxymethylepoxyquinomicin, NF- $\kappa \mathrm{B}$, nuclear factor- $\kappa \mathrm{B}$, I $\mathrm{B}$, inhibitory $\kappa \mathrm{B}$, IL- $1 \beta$, interleukin- $1 \beta$, TNF- $\alpha$, tumor necrosis factor- $\alpha$, JNK, c-jun N-terminal kinase, DMSO, dimethyl sulfoxide, GCK, glucokinase, GLUT, glucose transporter, PDX-1, pancreatic and duodenal homeobox-1, iNOS, inducible nitric oxide synthase, MTT, C,N-diphenyl-N'-4,5 dimethyl thiazol 2-yl tetrazolium bromide, siRNA, small interfering RNA ized by both insulin resistance and beta cell dysfunction [3], however, a deficit of beta cell mass in the subjects of type 2 diabetes has also been reported [4]. Maedler et al. have reported that glucose-induced production and secretion of interleukin-1 $\beta$ (IL-1 $\beta$ ) in beta cells induces beta cell apoptosis in a paracrine manner in human islets [5], suggesting that NF- $\mathrm{kB}$ may also play an important role in leading beta cell dysfunction in T2DM as well as T1DM [6].

Dehydroxymethylepoxyquinomicin (DHMEQ) is a novel low-molecular-weight NF- $\mathrm{KB}$ inhibitor which is derived from the antibiotic epoxyquinomicin $\mathrm{C}[7,8]$. DHMEQ is a unique inhibitor of NF- $\mathrm{B}$ acting at the level of nuclear translocation. DHMEQ inhibited tumor necrosis factor- $\alpha$ (TNF- $\alpha$ )-induced activation of $\mathrm{NF}-\kappa \mathrm{B}$ in human $\mathrm{T}$ cell leukemia Jurkat cells, while it did not inhibit the phosphorylation and degradation of inhibitory $\kappa \mathrm{B}(\mathrm{I} \kappa \mathrm{B})$, the nuclear transport of Smad2 and large $\mathrm{T}$ antigen, or TNF- $\alpha$-induced activation of $\mathrm{c}$-jun 
N-terminal kinase (JNK) [7]. DHMEQ has shown benefits as an anti-cancer and anti-inflammation drug in vitro and in vivo without apparent adverse toxicity $[7,9$, 10]. Thus DHMEQ treatment might be a possible therapy for both type 1 and type 2 diabetes as well as cancer or arthritis. In this study, we therefore investigated effects of DHMEQ on beta cell dysfunction induced by cytokine (TNF- $\alpha$ ) in rat insulinoma INS-1 cells.

\section{Materials and Methods}

\section{Materials}

INS-1 cell line was donated by Dr C.B. Newgard (Duke University, Durham, NC, USA). Cells were seeded in 24-well dishes coated with poly-L-lysine (Asahi Technoglass, Tokyo, Japan) for each study, except for the NF- $\kappa B$ activation assay. Recombinant rat TNF- $\alpha$ was purchased from Sigma (St. Louis, MO, USA).

\section{Inhibitor of $N F-\kappa B$}

Optically active (-)-DHMEQ was prepared as described previously [8]. It was dissolved in $100 \%$ dimethyl sulfoxide (DMSO) at $10 \mathrm{mg} / \mathrm{ml}$ and kept in aliquots at $-20^{\circ} \mathrm{C}$. Before use in cell culture, it was diluted with the medium described below to a final DMSO concentration of $0.1 \%$ or less, at which no effect of DMSO per se on NF- $\kappa$ B activity was observed. In each study, DHMEQ was added to the medium for 2 hours before TNF- $\alpha$ treatment. Since $10 \mu \mathrm{g} / \mathrm{ml} \mathrm{DH-}$ MEQ showed adverse effects on cell viability (Fig. 1), which was possibly due to drug toxicity, we used up to $5 \mu \mathrm{g} / \mathrm{ml}$ DHMEQ in this study.

\section{Cell culture and incubation}

INS- 1 cells were seeded 72 hours before use in the experiments and grown in monolayer culture in RPMI1640 medium (Sigma) containing $11.1 \mathrm{mmol} / 1 \mathrm{glu}-$ cose, as described previously [11]. The culture medium was supplemented with $10 \mathrm{mmol} / 1$ HEPES, $10 \%$ heat-inactivated fetal calf serum, $1 \mathrm{mmol} / \mathrm{l}$ sodium pyruvate, $2 \mathrm{mmol} / \mathrm{l} \mathrm{L}$-glutamine, $50 \mu \mathrm{mol} / \mathrm{l} \beta$-mercaptoethanol, and $60 \mu \mathrm{g} / \mathrm{ml}$ kanamycin ( $\mathrm{pH} 7.40)$. The cells were incubated at $37^{\circ} \mathrm{C}$ in a humidified $95 \%$ air $5 \% \mathrm{CO}_{2}$ atmosphere.

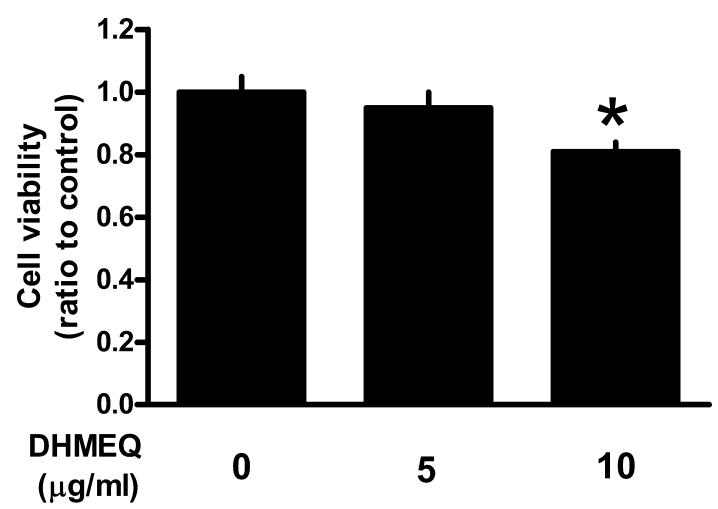

Fig. 1. Cell viability in INS-1 cells incubated with DHMEQ for 24 hours. Cell viability was evaluated by MTT assay. Values are means \pm S.E.M. $(n=5) . \quad * p<0.05$ vs. control.

\section{Insulin secretion experiments}

Twenty-six hours before the experiments, DHMEQ was added to the medium in DHMEQ treatment groups as a pre-treatment. After 2 hours of pre-treatment, cells were washed twice with PBS ( $\mathrm{pH} 7.40$, $37^{\circ} \mathrm{C}$ ) and given fresh RPMI-1640 medium containing $100 \mathrm{ng} / \mathrm{ml} \mathrm{TNF}-\alpha$ with or without DHMEQ. After 24 hours of incubation, glucose-stimulated insulin secretion was measured, as described previously [11]. Briefly, the cells were washed twice with PBS and preincubated in Krebs-Ringer bicarbonate (KRB) buffer containing $115 \mathrm{mmol} / 1 \mathrm{NaCl}, 4.7 \mathrm{mmol} / \mathrm{l} \mathrm{KCl}$, $2.6 \mathrm{mmol} / \mathrm{l} \mathrm{CaCl}{ }_{2}, 1.2 \mathrm{mmol} / 1 \mathrm{KH}_{2} \mathrm{PO}_{4}, 1.2 \mathrm{mmol} /$ $1 \mathrm{mgSO}_{4}, 20 \mathrm{mmol} / 1 \mathrm{NaHCO}_{3}, 16 \mathrm{mmol} / \mathrm{l} \mathrm{HEPES}$ and $0.1 \%$ BSA (glucose free) (pH 7.40) for 60 minutes. Cells were then washed once with glucose-free KRB-HEPES buffer and subsequently incubated for 60 minutes with KRB-HEPES buffer containing 2.8 or $11.1 \mathrm{mmol} / \mathrm{l}$ glucose. The incubation buffer was collected and centrifuged at $1.0 \times 10^{4} \mathrm{rpm}$ for 5 minutes. Insulin concentration was determined by enzyme immunoassay (Morinaga, Yokohama, Japan).

\section{MTT assay}

To evaluate cell viability, the C,N-diphenyl-N'-4,5 dimethyl thiazol 2-yl tetrazolium bromide (MTT) (Chemicon International, Temecula, CA, USA) assay method was used, as described previously [11]. Twenty-six hours before the experiments, DHMEQ was added in the medium of DHMEQ treatment group as a 
pre-treatment. After 2 hours of pre-treatment, cells were washed twice with PBS $\left(\mathrm{pH} 7.40,37^{\circ} \mathrm{C}\right)$ and given fresh RPMI-1640 medium containing 100 $\mathrm{ng} / \mathrm{ml} \mathrm{TNF}-\alpha$ with or without DHMEQ. After 24-hour incubation the cells were washed twice with PBS and then incubated at $37^{\circ} \mathrm{C}$ for 120 minutes with MTT and RPMI-1640 medium. To solubilize the formazan crystals at the end of incubation, isopropanol with $0.04 \mathrm{~N} \mathrm{HCl}$ was added to each well. The mixed solution was transferred to a 96-well microtitre plate, and immediately measured the absorbance on an ELISA plate reader with a test wavelength of $570 \mathrm{~nm}$ and a reference wavelength of $630 \mathrm{~nm}$.

\section{Quantitative real time RT-PCR analysis}

Twenty-six hours before the experiments, DHMEQ was added in the medium of DHMEQ treatment group as a pre-treatment. After 2 hours of pre-treatment, cells were washed twice with $\mathrm{PBS}\left(\mathrm{pH} 7.40,37^{\circ} \mathrm{C}\right)$ and given fresh RPMI-1640 medium containing $100 \mathrm{ng} / \mathrm{ml} \mathrm{TNF-} \alpha$ with or without DHMEQ. After 24-hour incubation, the cells were washed twice with PBS, and total RNA was extracted and reverse transcribed into cDNA, using an RNeasy Mini Kit (Qiagen, Valencia, CA, USA) and First-Strand cDNA Synthesis Kit (Amersham Biosciences, Buckinghamshire, UK), respectively. To validate changes in gene expression, quantitative real time RT-PCR analysis was performed with an Applied Biosystems Prism 7500 Fast Real-Time PCR System using TaqMan ${ }^{\circledR}$ Fast universal PCR master mix according to the manufacturer's specifications (Applied Biosystems Inc., Foster City, CA, USA). PCR was performed under the following conditions: initial denaturation at $95^{\circ} \mathrm{C}$ for 20 seconds followed by 40 cycles of $95^{\circ} \mathrm{C}$ for 3 seconds and $60^{\circ} \mathrm{C}$ for 30 seconds.

Validated TaqMan Gene Expression Assays were used for the assay. The TaqMan probes and primers for glucokinase (GCK) (assay identification number Rn00561265_m1), GLUT2 (assay identification number Rn00563565_m1) and pancreatic and duodenal homeobox-1 (PDX-1) (assay identification number Rn00755591_m1) were assay-on-demand gene expression products (Applied Biosystems). The rat beta actin gene was used as an endogenous control (assay identification number Rn00667869_m1, Applied Biosystems). Pairs of primers and the probe for insulin mRNA were designed from rat insulin-1 mRNA
(NM_019129) and the primers used were: forward 5'GGG TGT GTA GAA GAA ACC ACG TT-3', reverse 5'-CTG CCC AGG CTT TTG TCA AA-3'. Because the efficiency of the target gene amplification and of beta actin amplificaton were approximately equal, the $\Delta \Delta \mathrm{C}_{\mathrm{T}}$ method recommended by the manufacturer was used to compare the relative expression levels between treatments.

\section{$N F-\kappa B$ activation assay}

INS-1 cells were seeded in a $60-\mathrm{mm}$ dish coated with poly-L-lysine (Asahi Technoglass, Tokyo, Japan) 72 hours before the experiments. Three hours before the experiments, DHMEQ was added in the medium of DHMEQ treatment group as a pre-treatment. After 2 hours of pre-treatment, cells were washed twice with PBS ( $\mathrm{pH} 7.40,37^{\circ} \mathrm{C}$ ) and given fresh RPMI-1640 medium containing $100 \mathrm{ng} / \mathrm{ml} \mathrm{TNF-} \alpha$ with or without DHMEQ, then incubated for 60 minutes. Then the cells were washed twice with cold PBS, and nuclear proteins were extracted using a Nuclear Extract Kit (Active Motif, Carsbad, CA, USA). Activation of $\mathrm{NF}-\kappa \mathrm{B}$ was quantified with an ELISA-based kit using attached oligonucleotides binding to an NF- $\kappa B$ consensus site and detected by an anti-p65 subunit antibody, according to the manufacturer's instructions (Trans-AM NF- $\kappa B$, Active Motif).

\section{Statistical analysis}

All values are presented as means \pm S.E.M. Analysis of variance (ANOVA) followed by Fisher's LSD was used to evaluate the differences between the groups. A $p$ value less than 0.05 was considered statistically significant.

\section{Results}

Treatment with100 ng/ml TNF- $\alpha$ significantly activated NF- $\mathrm{kB}$ in INS- 1 cells $(1.0 \pm 0.5$ vs. $16.0 \pm 5.2$ in control vs. TNF- $\alpha, \mathrm{p}<0.05$ ) (Fig. 2). Five $\mu \mathrm{g} / \mathrm{ml} \mathrm{DH-}$ MEQ effectively suppressed this NF- $\kappa B$ activation induced by TNF- $\alpha$ to nearly normal level $(2.5 \pm 0.5$, $\mathrm{p}<0.05$ vs. TNF- $\alpha$ ) (Fig. 2).

INS-1 cells treated with $100 \mathrm{ng} / \mathrm{ml} \mathrm{TNF-} \alpha$ for 24 hours showed decreased basal and glucose-stimulated insulin secretion compared to control $(10.3 \pm 0.8$ 


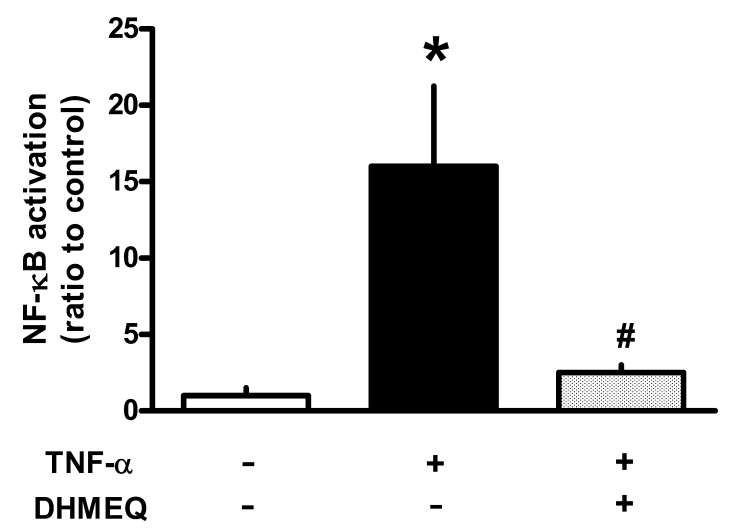

Fig. 2. NF- $\kappa \mathrm{B}$ activation in INS-1 cells. INS-1 cells were incubated with $100 \mathrm{ng} / \mathrm{ml} \mathrm{TNF-} \alpha$ and treated with or without $5 \mu \mathrm{g} / \mathrm{ml}$ DHMEQ for 1 hour. Nuclear proteins of the cells were extracted and activation of NF- $\mathrm{\kappa B}$ was quantified with an ELISA-based kit. Values are means \pm S.E.M. $(n=3) . \quad{ }^{*} \mathrm{p}<0.05$ vs. control. ${ }^{*} \mathrm{p}<0.05$ vs. cells incubated with $100 \mathrm{ng} / \mathrm{ml}$ TNF- $\alpha$ without DHMEQ.

vs. $6.2 \pm 0.3 \mathrm{ng} / \mathrm{ml}$ in basal $(\mathrm{p}<0.01), 21.4 \pm 0.9$ vs. $10.1 \pm 0.2 \mathrm{ng} / \mathrm{ml}$ in glucose-stimulated $(\mathrm{p}<0.01)$, respectively) (Table 1A and Fig. 3). While there was no significant change in basal insulin secretion by $\mathrm{DH}-$ MEQ treatment, $5 \mu \mathrm{g} / \mathrm{ml}$ DHMEQ partially ameliorated TNF- $\alpha$-induced inhibition of glucose-stimulated insulin secretion $(12.9 \pm 0.6 \mathrm{ng} / \mathrm{ml}, \mathrm{p}<0.01 \mathrm{vs}$. TNF- $\alpha)$ and this effect of DHMEQ was dose-dependent (Table $1 \mathrm{~A}$ and Fig. 3).

DHMEQ also partially, but significantly ameliorated insulin mRNA expression level suppressed by TNF- $\alpha(0.57 \pm 0.04$ vs. $0.78 \pm 0.05, \mathrm{p}<0.01) \quad($ Table 1B). GCK, GLUT2 and PDX-1 mRNA expression levels in INS- 1 cells were also $20-50 \%$ suppressed by
TNF- $\alpha$ (Table 1B). DHMEQ significantly ameliorated GCK and GLUT2 mRNA expression levels suppressed by TNF- $\alpha$ as well as insulin mRNA expression level $(0.71 \pm 0.02$ vs. $0.87 \pm 0.04, p<0.01$, $0.81 \pm 0.04$ vs. $0.96 \pm 0.06, \mathrm{p}<0.05$ in GCK and GLUT2, respectively), while the change in PDX-1 mRNA expression level did not reach statistical significance $(0.52 \pm 0.03$ vs. $0.69 \pm 0.05, p=0.06)$ (Table 1B).

TNF- $\alpha(100 \mathrm{ng} / \mathrm{ml})$ also suppressed the cell viability in INS-1 cells compared to control $(1.00 \pm 0.03$ vs. $0.68 \pm 0.01, \mathrm{p}<0.01)($ Table $1 \mathrm{C})$. Five $\mu \mathrm{g} / \mathrm{ml}$ DHMEQ significantly, but again partially, ameliorated this TNF- $\alpha$-induced suppression in cell viability $(0.81 \pm 0.02, \mathrm{p}<0.01$ vs. TNF- $\alpha)($ Table $1 \mathrm{C})$.

\section{Discussion}

In this study we demonstrated that DHMEQ suppressed NF- $\kappa \mathrm{B}$ activation and ameliorated beta cell dysfunction induced by TNF- $\alpha$. This study is the first study which confirmed the efficacy of this compound in pancreatic beta cells.

In this study, TNF- $\alpha$ activated NF- $\kappa \mathrm{B}$ and decreased cell viability as well as basal and glucose-stimulated insulin secretion, as previously reported [2, 12, 13]. Because the activation of NF- $\mathrm{KB}$ induces inducible nitric oxide synthase (iNOS) expression and NO production [2], these described effects of TNF- $\alpha$ might be mediated by iNOS expression. However, recent study has also shown that the abrogation of NO production by small interfering RNA (siRNA), which silenced iNOS gene expression, did not prevent INS-1E cells

Table 1. Effects of $5 \mu \mathrm{g} / \mathrm{ml}$ DHMEQ on $100 \mathrm{ng} / \mathrm{ml} \mathrm{TNF}-\alpha$-induced beta cell dysfunction

\begin{tabular}{|c|c|c|c|}
\hline & Control & TNF- $\alpha$ & TNF- $\alpha+$ DHMEQ \\
\hline \multicolumn{4}{|l|}{ A. Insulin secretion $(n=6)$} \\
\hline Basal (2.8 mM glucose) & $10.3 \pm 0.8$ & $6.2 \pm 0.3 * *$ & $6.6 \pm 0.5^{* *}$ \\
\hline Stimulated (11.1 mM glucose) & $21.4 \pm 0.9$ & $10.1 \pm 0.2 * *$ & $12.9 \pm 0.6^{* * \# \#}$ \\
\hline \multicolumn{4}{|l|}{ B. mRNA expression $(n=9)$} \\
\hline Insulin & $1.00 \pm 0.02$ & $0.57 \pm 0.04 * *$ & $0.78 \pm 0.05^{* * \# \#}$ \\
\hline Glucokinase & $1.00 \pm 0.03$ & $0.71 \pm 0.02 * *$ & $0.87 \pm 0.04 * * \#$ \\
\hline GLUT-2 & $1.00 \pm 0.04$ & $0.81 \pm 0.04 *$ & $0.96 \pm 0.06^{\#}$ \\
\hline PDX-1 & $1.00 \pm 0.09$ & $0.52 \pm 0.03 * *$ & $0.69 \pm 0.05^{* *}$ \\
\hline C. Cell viability (MTT assay) $(n=6)$ & $1.00 \pm 0.03$ & $0.68 \pm 0.01 * *$ & $0.81 \pm 0.02 * * \# \#$ \\
\hline
\end{tabular}

Values are expressed as means \pm S.E.M. (A; $\mathrm{ng} / \mathrm{ml}, \mathrm{B}$ and $\mathrm{C}$; ratios to control). ${ }^{*} \mathrm{p}<0.05,{ }^{* *} \mathrm{p}<0.01$ vs. control, and ${ }^{\#} \mathrm{p}<0.05,{ }^{\# \#} \mathrm{p}<0.01$ vs. TNF- $\alpha$ group.

ANOVA followed by Fisher's LSD was used for analysis. 


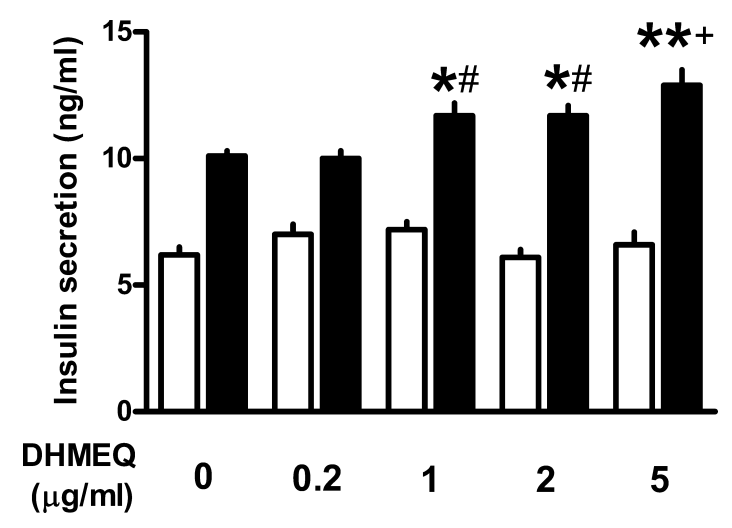

Fig. 3. Basal and glucose-stimulated insulin secretion in INS-1 cells treated with $100 \mathrm{ng} / \mathrm{ml} \mathrm{TNF- \alpha}$ and various concentrations of DHMEQ for 24 hours. To measure glucose-stimulated insulin secretion, INS-1 cells were incubated with $2.8 \mathrm{mmol} / \mathrm{l}$ (open columns) or $11.1 \mathrm{mmol} / 1$ (closed columns) glucose for 60 minutes. Values are means \pm S.E.M. $(n=6) . * p<0.05, * * p<0.01$

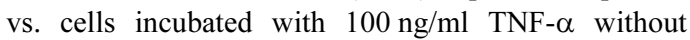
DHMEQ. ${ }^{\#} \mathrm{p}<0.05,{ }^{+} \mathrm{p}<0.01$ vs. cells incubated with $100 \mathrm{ng} / \mathrm{ml} \mathrm{TNF}-\alpha$ and $0.2 \mu \mathrm{g} / \mathrm{ml}$ DHMEQ.

from cytokine-induced apoptosis, suggesting iNOS independent effects of NF- $\kappa \mathrm{B}$ [14].

On the other hand, whereas in this study $5 \mu \mathrm{g} / \mathrm{ml}$ DHMEQ suppressed TNF- $\alpha$-induced NF- $\kappa B$ activation to nearly normal level as shown in the previous study [7], TNF- $\alpha$-induced beta cell dysfunction was not completely ameliorated by the same dose of DHMEQ. These partial effects $(\sim 50 \%)$ of DHMEQ against TNF- $\alpha$-induced beta cell dysfunction may be due to the fact that TNF- $\alpha$-induced beta cell dysfunction is mediated not only by NF- $\kappa \mathrm{B}$ activation, but also by other mediators, such as the $\mathrm{JNK} / \mathrm{p} 38$ pathway [2, 6]. Partial effects of DHMEQ against TNF- $\alpha$ were also confirmed in various mRNA expression levels associated with beta cell function, i.e., insulin, GCK, GLUT2 and PDX-1. The improvement in glucosestimulated, but not basal, insulin secretion in this study also suggests the partial recovery of glucose responsiveness as well as insulin synthesis.

Since DHMEQ ameliorated both insulin secretion and cell viability in this study, we could not distinguish the effect of NF- $\kappa \mathrm{B}$ on beta cell function itself such as glucose-stimulated insulin secretion from that on beta cell viability. Although Norlin et al. reported that IкB over-expression in mice severely attenuated glucose-stimulated insulin secretion despite only a small change in beta cell mass, suggesting the effect of
$\mathrm{NF}-\kappa \mathrm{B}$ on beta cell function independently of beta cell viability [15], the precise mechanism of NF- $\kappa B$ pathway on beta cell function remains to be determined. While NF- $\kappa B$ has been shown to regulate the expression of numerous genes including PDX-1 [16], the effect of DHMEQ on PDX-1 mRNA expression in this study did not reach statistical significance. This result may suggest that the significant improvement of insulin, GCK and GLUT2 mRNA expression levels in this study was due to the effect of nuclear translocation of PDX-1 rather than increased PDX-1 mRNA expression level. Whether DHMEQ can promote nuclear translocation of PDX-1 remains to be elucidated.

While our results suggest the adverse effects of TNF- $\alpha$ on beta cell are at least partially mediated by $\mathrm{NF}-\kappa \mathrm{B}$ as previously reported $[2,6]$, others have reported that anti-apoptotic role of NF- $\mathrm{KB}$ in TNF- $\alpha$ induced beta cell apoptosis $[17,18]$. Papaccio et al. have reported that the first phase of IL- $1 \beta$ induced NF$\kappa \mathrm{B}$ activity led to a beneficial increase in beta cell defense/repair protein expression, while the second phase induced iNOS transcription in rat islets, suggesting a biphasic role of NF- $\kappa \mathrm{B}$ [19]. Furthermore, Hammar et al. reported that the transient and moderate $\mathrm{NF}-\kappa \mathrm{B}$ activation induced by extracellular matrix was involved in both spreading and glucose-stimulated insulin secretion of primary rat islets [20]. They speculated that transient and/or low NF- $\mathrm{KB}$ activity is beneficial, whereas sustained and/or strong NF- $\kappa B$ activity is deleterious to the pancreatic beta cell [20]. Taken together, the discrepancy among the studies may be due to the different cell types and species, and/ or different timing and degree of NF- $\kappa \mathrm{B}$ activation. It should be also noted that the role of NF- $\mathrm{KB}$ on cell viability could be different between primary islet cells and insulin-secreting beta cell lines. Thus, further investigation including in vivo study will be needed to clarify the role of NF- $\mathrm{\kappa B}$ on beta cells.

To summarize, we report that DHMEQ, a novel $N F-\kappa B$ inhibitor, suppressed TNF- $\alpha$-induced NF- $\kappa B$ activation and ameliorated the inhibition of glucosestimulated insulin secretion and cell viability in INS-1 cells. Inhibition of activated NF- $\mathrm{KB}$ in beta cells may be important to ameliorate beta cell dysfunction in diabetes. 


\section{Acknowledgements}

The authors thank Akira Shimada, Kenji Watanabe for helpful suggestions. This work was supported in part by the Keio Gijuku Fukuzawa Memorial Fund for the Advancement of Education and Research.

\section{References}

1. Meier JJ, Bhushan A, Butler AE, et al. (2005) Sustained beta cell apoptosis in patients with long-standing type 1 diabetes: indirect evidence for islet regeneration? Diabetologia 48: 2221-2228.

2. Eizirik DL, Mandrup-Poulsen T (2001) A choice of death - the signal-transduction of immune-mediated beta-cell apoptosis. Diabetologia 44: 2115-2133.

3. Kahn SE (2001) Clinical review 135: The importance of beta-cell failure in the development and progression of type 2 diabetes. J Clin Endocrinol Metab 86: 40474058.

4. Butler AE, Janson J, Bonner-Weir S, et al. (2003) Beta-cell deficit and increased beta-cell apoptosis in humans with type 2 diabetes. Diabetes 52: 102-110.

5. Maedler K, Sergeev P, Ris F, et al. (2002) Glucoseinduced beta cell production of IL-1beta contributes to glucotoxicity in human pancreatic islets. $J$ Clin Invest 110: 851-860.

6. Donath MY, Storling J, Maedler K, et al. (2003) Inflammatory mediators and islet beta-cell failure: a link between type 1 and type 2 diabetes. J Mol Med 81: 455-470.

7. Ariga A, Namekawa J, Matsumoto N, et al. (2002) Inhibition of tumor necrosis factor-alpha -induced nuclear translocation and activation of NF-kappa B by dehydroxymethylepoxyquinomicin. $J$ Biol Chem 277: 24625-24630.

8. Suzuki Y, Sugiyama C, Ohno O, et al. (2004) Preparation and biological activities of optically active dehydroxymethylepoxyquinomicin, a novel NF-kappaB inhibitor. Tetrahedron 60: 7061-7066.

9. Umezawa K (2006) Inhibition of tumor growth by NFkappaB inhibitors. Cancer Sci 97: 990-995.

10. Wakamatsu K, Nanki T, Miyasaka N, et al. (2005) Effect of a small molecule inhibitor of nuclear factorkappaB nuclear translocation in a murine model of arthritis and cultured human synovial cells. Arthritis Res Ther 7: R1348-R1359.
11. Kawai T, Hirose H, Seto Y, et al. (2001) Chronic effects of different fatty acids and leptin in INS-1 cells. Diabetes Res Clin Pract 51: 1-8.

12. Tsiotra PC, Tsigos C, Raptis SA (2001) TNFalpha and leptin inhibit basal and glucose-stimulated insulin secretion and gene transcription in the HIT-T15 pancreatic cells. Int J Obes Relat Metab Disord 25: 1018-1026.

13. Zhang S, Kim KH (1995) TNF-alpha inhibits glucoseinduced insulin secretion in a pancreatic beta-cell line (INS-1). FEBS Lett 377: 237-239.

14. De Paula D, Bentley MV, Mahato RI (2007) Effect of iNOS and NF-kappaB gene silencing on beta-cell survival and function. $J$ Drug Target 15: 358-369.

15. Norlin S, Ahlgren U, Edlund H (2005) Nuclear factor$\{$ kappa\}B activity in $\{$ beta\}-cells is required for glucose-stimulated insulin secretion. Diabetes 54: 125-132.

16. Cardozo AK, Heimberg H, Heremans Y, et al. (2001) A comprehensive analysis of cytokine-induced and nuclear factor-kappa B-dependent genes in primary rat pancreatic beta-cells. J Biol Chem 276: 48879-48886.

17. Chang I, Kim S, Kim JY, et al. (2003) Nuclear factor kappaB protects pancreatic beta-cells from tumor necrosis factor-alpha-mediated apoptosis. Diabetes 52: 1169-1175.

18. Liuwantara D, Elliot M, Smith MW, et al. (2006) Nuclear factor-kappaB regulates beta-cell death: a critical role for A20 in beta-cell protection. Diabetes 55: 24912501.

19. Papaccio G, Graziano A, D'Aquino R, et al. (2005) A biphasic role of nuclear transcription factor (NF)-kap$\mathrm{paB}$ in the islet beta-cell apoptosis induced by interleukin (IL)-1 beta. J Cell Physiol 204: 124-130.

20. Hammar EB, Irminger JC, Rickenbach K, et al. (2005) Activation of NF-kappaB by extracellular matrix is involved in spreading and glucose-stimulated insulin secretion of pancreatic beta cells. $J$ Biol Chem 280: 30630-30637. 